Scientia Militaria vol 40, no 3, 2012, pp.200-221. doi: 10.5787/40-3-1033

\title{
Changing Attitudes among South African Prisoners of War towards their Italian Captors during World War II, 1942-1943
}

\author{
Karen Horn •
}

\begin{abstract}
The Battle of Sidi Rezegh in November 1941 and the fall of Tobruk in June 1942 were disastrous for South Africa. At Sidi Rezegh, the entire $5^{\text {th }}$ South African Infantry Brigade was lost and at Tobruk the following year more than 10000 South Africans were captured by German forces. As if the shock of becoming prisoners of war (POWs) was not bad enough, most South Africans were horrified when the Germans promptly handed them over to the Italians, who were to deal with the logistics for the thousands of POWs, first housing them in temporary camps in North Africa, and then transporting them to Italy. Once on the European continent, the South African POWs found themselves in better-organised prison camps, although most POW accommodation was a far cry from what the Geneva Convention required. Some were fortunate to be assigned to labour detachments, where they were in a better position to take control of their circumstances with regard to living conditions and food and even gaining a degree of freedom of movement. During each of the stages of their captivity under the Italians, the South African POWs displayed changing attitudes towards their captors. For the most part, the Italian forces in North Africa were viewed with disrespect and sometimes with cynical amusement. The antagonism towards Italians quickly changed to intense hatred when POWs suffered severe deprivations in the cargo holds of the boats that transported them to Italy. Once in Italy, however, the POWs came into contact with Italian camp

- Karen Horn is a lecturer at the Department of Curriculum Studies in the Faculty of Education at Stellenbosch University. This article is based on research towards her $\mathrm{PhD}$ thesis entitled South African prisoner-of-war experience during and after World War II: 1939-c1950.
\end{abstract}


guards who, in many cases, displayed a remarkable lack of interest in the prisoners and in the war. The changing attitudes of South African POWs towards their Italian captors reflect to an extent their changing circumstances as captives; however, their behaviour towards their captors also reveal how the POWs adapted to and accepted their POW identity. Ultimately, the POWs contact with the enemy captors changed the way they viewed their part in the war, and this article looks at examples of the shifting mind-sets until the Armistice in 1943 once again changed the state of affairs for the POWs. ${ }^{1}$

Keywords: Prisoners of war (POWs), World War II, South Africa, Italy, Sidi Rezegh, Tobruk, Lieutenant General Erwin Rommel, Major General H.B. Klopper

\section{Introduction}

South African prisoner-of-war (POW) experience during World War Two can be viewed as a collective experience, in that all of those captured lived through remarkably similar experiences, but simultaneously experiences were also of an individual nature because each POW saw and lived through the war and his captivity from a uniquely contextualised perspective. A case in point is the way those South Africa who were captured during the Battle of Sidi Rezegh and the fall of Tobruk in June 1942 viewed their Italian captors. The POW experience of these men, and specifically those whose narratives were available for this study, included the initial shock and deprivations of the so-called "hell camps" of North Africa. The second phase of their captivity under Italian authority involves their transportation by cargo boats to Italy. The last phase, and the part of their experience that involved the most significant paradigm shift regarding their captors, comprises their stay in Italy until the Italian Armistice on 8 September 1943. This article looks at each phase as a collective experience but also highlights individual POW perspectives where these indicate noteworthy deviations from the general experience. The specific aim of the article is to highlight how South African POWs viewed their Italian captors and how their opinion of their captors changed during each of the three phases of their captivity under Italian authority. 
The article arises from research towards a doctoral study. A significant component of the research consisted of collecting oral testimony and other first-hand accounts of South African POW experience, including diaries and memoirs. As scholarly work on South African POW experience is extremely limited and lacks meaningful archival research, the collections of the Department of Defence Military archives, the National Archives as well as the collections at the Ditsong National Museum of Military History in Johannesburg and the sources at the Castle of Good Hope Military Museum in Cape Town were consulted.

With regard to published work on South African POW experience, Maxwell Leigh's work, Captives Courageous, is the most noteworthy. However, it is a basic narrative compiled from a selection of personal memoirs and lacks in-depth research and analysis. Paul Schamberger's book, Interlude in Switzerland, looks at the experiences of those South Africans who successfully escaped and reached the safety of neutral Switzerland. ${ }^{2}$ In the international academic arena, research on the historical experience of POWs is more prolific, and historians like Bob Moore and Kent Fedorowich, Barbara Hately-Broad, Arieh J. Kochavi, S.P. Mackenzie and Adrian Gilbert have all contributed significantly. ${ }^{3}$ In Prisoners of war and their captors, for instance, a number of authors contribute chapters on varying aspects of the topic. In Chapter one, Moore investigates the problem faced by the British government as well as by Dominion governments on the matter of accommodation and transportation of Axis POWs. Other themes include the role of the Geneva Convention (Joan Beaumont), the experiences of black POWs (David Killingray) and the role of the Dominion governments in the formulation of policy regarding POWs (J.F. Vance). ${ }^{4}$ Roger Absalom's work on British POWs in Italy, especially Hiding History: The Allies, the Resistance and the Others in Occupied Italy 1943-1945 was particularly useful for this article as it deals with issues such as the relationships between Italian peasants and British escapees, even though South African POWs are not specifically mentioned in Hiding History. ${ }^{5}$

From the above, however, it is obvious that most international historians approach the topic thematically and do not differentiate between the different Commonwealth and Allied nationalities in European prisonerof-war camps. Undeniably, there are many other aspects of POW 
experience that an author may deem as more important than nationality, especially if many of those nationalities involved in the war formed part of the Commonwealth, which was seen as a common political unit.

However, there are exceptions that investigate POW experience in its totality from the point of view of a specific nationality. One such publication is W. Wynne Mason's Prisoners of war: Official history of New Zealand in the Second World War 1939-45. ${ }^{6}$ Jonathan Vance's work on Canadian POW experience is another example of such research. In this work, Vance looks at Canadian POWs throughout the twentieth century. Most notably, in comparison to the situation in South Africa, it is clear from Vance's research that, by the time World War Two started, Canada, although also a dominion of Great Britain, was better able to provide assistance to the Red Cross as this country was not directly affected by the war. This is a legitimate point, which is emphasised by numerous South African POWs who referred to the Canadian Red Cross parcels as the best in terms of quality and quantity when compared to parcels from other Allied nations. $^{7}$

Although the tendency to categorise all Commonwealth soldiers as "British" is functional when the focus falls on themes, this approach does not take into account the unique context of each nationality. Moreover, in the case of South Africans, the political and social milieu was especially relevant and would have influenced South African war experience as well as relations of captivity by enemy forces. It is, however, necessary to consider South Africa's unique war context as it illuminates the peculiarity and complexity of the country's race and class relations. At the start of the war, the Union was, obviously, divided among political, economic, class and, especially, racial lines. While numerous English-speaking South Africans did not think twice about volunteering, many more Afrikaners were reluctant to do so, having grown up listening to their grandparents' stories of British concentration camps during the South African War. Although many Afrikaners volunteered, the majority of them did so mostly for financial reasons and not because they felt loyalty towards the British Empire or a commitment to the cause of the war. ${ }^{8}$ Furthermore, all of the former POWs who agreed to interviews were white South Africans and although an effort was made to locate veterans of the non-white forces, none was found. Similarly, the memoirs consulted for the study on which this article is based 
were also written by white veterans, leaving the researcher with a one-sided view of the wartime race relations situation. Occasional references to nonwhite forces can, however, can be found in memoirs and in some cases in oral testimony, providing glimpses of non-white POW experiences. That said, we do know that German and Italian treatment of black Allied soldiers was for the most part dreadful, as neither the Germans nor the Italians seemed to regard the Geneva Convention as having any bearing on the rights of black forces as they did not view them as regular forces. African and coloured POWs were therefore in the worst possible position and possibly had to rely on each other more so than other POWs. Many non-European soldiers from different parts of the Commonwealth endured bad treatment from their captors, and several were shot if they were seen to be too much trouble. $^{9} \quad$ These obvious differences between non-white, English- and Afrikaans-speaking South Africans regarding South Africa's role in World War Two make for interesting research in the experience of POWs, as they were all forced into the same situation, and in some cases even the same prison camps, regardless of the racial, social or ideological differences between them.

\section{Phase One: Capture}

It is fairly safe to say that the morale among the $2^{\text {nd }}$ South African Infantry Division must have been less than positive in the weeks before the fall of Tobruk in June 1942. In December the previous year, a significant number of South Africans were captured at the Battle of Sidi Rezegh, and this, together with the seemingly endless digging of defences along the 30-mile bottleneck between the Mediterranean Sea and the Qattara Depression at El Alamein, demotivated many. ${ }^{10}$ Added to their frustration was the belief among some South Africans that their defences were inadequate, as Michael de Lisle of the $2^{\text {nd }}$ Anti-Aircraft Regiment stated in his memoirs, "minefields had not been maintained and defensive positions had filled with sand". ${ }^{11}$ To make matters worse, many South Africans regarded the Afrika Korps and its commander, Lieutenant General Erwin Rommel, as a superior strategist. Some historians believe that the entire Eighth Army developed an inferiority complex regarding the Germans, a view supported by the testimonies and memoirs of the war correspondent Ike Rosmarin and David Brokensha, a dispatch rider in the $2^{\text {nd }}$ South Africa Division Signal Company. ${ }^{12}$ Rosmarin concluded, "Eighth Army Command was simply out of its depth 
when faced with the quirky genius of the 'Desert Fox'."13 Brokensha stated that Rommel “was our favourite General, I won't say our only favourite German General, but for some reason we all ... he had a very good name as a proper soldier, and very efficient." ${ }^{14}$

When Rommel advanced on Tobruk in 1942, the ensuing battle was characterised by chaos, misunderstandings and in some cases, seemingly phantom orders. Rosmarin, for instance, described the combat as "terrifying [but] worst of all was the fact that we did not know what was happening as there were no orders from our officers. Confusion reigned with fear and panic." 15 With regard to orders, some testimonies indicate that a so-called "every man-for-himself" order was given, while others recall orders to the contrary, including one which stated that a "tank-hunting" force was to be sent out during the night of 20 June. ${ }^{16}$

In this highly volatile atmosphere, the accuracy of many of these testimonies is doubtful, as many of them do not correspond with other known positions. For instance, the account of the events of 20 and 21 June by Major General H.B. Klopper, commanding officer of the forces at Tobruk, contradicts that of other statements made after the war. According to Klopper, he "stressed to [Lieutenant] General [William] Gott that he felt very uneasy at the prospect at being invested [in Tobruk] and understood from [Gott] that the higher command would make every effort to prevent this." ${ }^{17}$ In contrast, a 1946 interview with Colonel H. McA. Richards, commander of the Divisional Artillery, paraphrased Klopper's earlier remark that if the Australians could hold Tobruk, then so could the South Africans. The indecision and disagreements between those in command affected everyone at Tobruk - for instance, the Cape Town Highlanders received an order stating, "[i]f anyone leaves Tobruk now, they'll be classified as a deserter". One of those Highlanders, Gordon Fry, believed that had an order of "every man for himself" been given, he would have been able to escape capture, something that troubled him deeply throughout his time as a POW. ${ }^{18}$ Others, however, simply took it for granted that it was a case of every man for himself and many attempted to escape. However, the order seems never to have been given officially, as none of the men could say reliably where the order originated. 
Nevertheless, once the soldiers became POWs, many of them felt a need to apportion blame, and in most cases, the leadership of the South African forces was held responsible. For instance, Clive Luyt of the $2^{\text {nd }}$ Anti-Aircraft Regiment believed that Klopper was liable as he was "straight from a desk in Pretoria [...] they sent [Klopper] up they stuck him in charge of Tobruk and about three days later Rommel and Co attacked Tobruk and we all ended in the bag". ${ }^{19}$ Dick Dickinson of the Transvaal Scottish Regiment, however, made it clear that he did not blame Klopper for the surrender, as "you know Tobruk wasn't in the same situation that it was when the Australians held it, I don't think Klopper had a chance." 20 Dickinson did, however, blame Klopper for apparently ordering the men not to attempt escape following the surrender order, as "General Klopper apparently had said we must not, not try and get out, and I was very critical of that." 21

The widely held belief among soldiers and those in command that Klopper's appointment was ill-advised was the result of inadequate, and in many cases inaccurate information regarding events surrounding the fall of Tobruk. However, rumours began to spread and accusations of cowardice were aimed at the ordinary soldiers in the Union Defence Force, which may go some way to explain the way in which many South Africans tried to justify their capture by enemy forces. ${ }^{22}$ For instance, a prominent aspect in many of the testimonies is the claim that they were captured "unfairly", or that they had not really been involved in the battle, as is evident in the account by Fred van Alphen Stahl, a volunteer in the $2^{\text {nd }}$ Anti-Aircraft Regiment. Van Alphen Stahl felt aggrieved at becoming a prisoner and described his experience as follows:

... of course your first feelings as a prisoner war, this is the end [...] I haven't

... I wasn't busy fighting at the time [...] we didn't even realise it was Tobruk [...] and the next morning we were ..., getting ready, getting our guns in order again, and a signal just came in and they said destroy your guns, destroy your vehicles, Tobruk has fallen ... You are now prisoners of war. ${ }^{23}$

Similarly, Fred Geldenhuis of the South African Police Brigade, explained that they were left without transport and weapons, and that not even one shot was fired by his Brigade at the time of the battle. Remarkably, Geldenhuis also claimed that he had been in Klopper's “dugout 
[preparing] Molotov cocktails” when Klopper made known his intention to surrender. ${ }^{24}$

Considering the common state of mind in the $2^{\text {nd }}$ Division, the general high regard for Rommel and the chaos of the battle, it is perhaps not surprising that most South African POWs reacted negatively to the news that they were to be handed over to the Italians, even if, as reported in some cases, the news was delivered by Rommel himself. Bernard Schwikkard of the Transvaal Scottish remembers that Rommel informed the group of POWs that he was "sorry to be handing us over to the Italians, but he needed all his soldiers to do the fighting. [Rommel] indicated that, as soldiers, the Italians were a miserable lot." 25 Rommel's opinion about the Italians seems to have influenced some South African's view of their captors. One example is Wessel Oosthuizen of the Police Brigade, whose attitude towards the Italians was not only remarkably similar to that of Rommel's, but seemed to have remained unchanged until 2010, when Oosthuizen stated during an interview that, although he did not want to place the Italians in a bad light, they did not compare well to the German soldiers. ${ }^{26}$

Both the Germans and the South Africans viewed the Italians as inferior and to a certain extent, the Germans acted on this by siding with the South African POWs in cases where the Italians tried to take advantage of their prisoners. One incident, which shows this, was when a South African exchanged his watch for a helmet filled with water to revive a friend during a forced march. A German soldier who witnessed the incident intervened by punching the Italian, replacing the brackish water with clean water from his own water can, and by finally returning the watch to the POW. ${ }^{27}$ The general high regard for Rommel among South African POWs, Rommel's successful taking of Tobruk and the negative attitude among Germans, not least Rommel himself regarding their Italian allies, seemed to have been the main factors that shaped the South African's initial opinion of their Italian captors.

When the Germans moved on and the Italians assumed complete control of the thousands of Allied POWs, it soon became evident that the Italians were ill-prepared to deal with the large number of captives. As a result, the provision of food and water was sporadic, something which is emphasised in most POW narratives of their experience in North Africa. 
The desperation among prisoners to survive amidst the lack of basic provisions often forced POWs to cower to their captors in an attempt to ensure they receive their share when the scarce foodstuffs arrived. Initially, the POWs were accommodated in temporary camps, which in most cases were simple wire enclosures. Bill Hindshaw of the Rand Light Infantry remembers, "water was the thing, food and water ... but water was the thing". When he and fellow POWs finally reached Italy, they were able to weigh themselves. Bill had lost fifty pounds $(22,7 \mathrm{~kg})$ since his capture. ${ }^{28}$ No archival evidence could be found and none of the oral testimonies or memoirs referred to the delivery of Red Cross parcels or to inspections of POW camps in North Africa at that time.

Initially, men of all nationalities were grouped together in the temporary camps around Tobruk and Benghazi, and it is in testimony of this early stage of captivity that attitudes regarding race and nationality become clear. While some historians view troubled race relations as distinctive to South Africans, memoirs show otherwise, indicating that generalisations are not always appropriate as some South Africans expressed racist attitudes in their memoirs while others emphasised the good relationships that existed between South Africans of different races. One such example is that of Ben Hermer, a medical officer with the $17^{\text {th }}$ Field Ambulance, and his batman July Monaremi, who supported him throughout the battles in North Africa. ${ }^{29}$ On the other hand, South Africans did express negative attitudes regarding race, as was the case with Dennis Mugglestone of the $6^{\text {th }}$ Infantry Police Brigade who noted dispassionately in his memoirs how Germans shot dead black POWs because they "were too drunk to move any further, and the Jerries [Germans] could not be worried. This was the result of the liquor [the black soldiers] stole from Battalion HQ the previous night." ${ }^{\text {,3 }}$ Racism was, however, not limited to South Africans as can be seen in the observations of other dominion POWs. A POW belonging to New Zealand's forces described "South African Blacks" and "Springboks" as two separate groups, and makes a point that while in POW camp in Tobruk "all conventional values were gone. The private no longer deferred to his officer nor black man to white."31

The use of local Senussi tribesmen to guard the camps did nothing to raise respect among POWs toward their Italian captors. L.G. Tupper of the Kaffrarian Rifles, described them as "a lot of black Senussi bastards 
guarding us and they would shoot for the slightest provocation. I remember one chap who showed them the ' $V$ ' for victory sign and was shot."32 A member of the Middelandse Regiment, Jack Mortlock, described the behaviour of the Senussi guards as appalling, leaving Mortlock with a desire for revenge. According to Mortlock, the Senussi guards -

... endeavoured to make their wishes known by bashing you about with a rifle butt. I believe there were cases of prisoners being shot by these creatures. Furthermore, if they noticed watches, fountain pens etc, these were immediately ripped off. It was indeed a lucky thing for the Senussis that none of the prisoners whom they handled were (sic) in the victorious Eight Army advance in the latter part of $1942 .{ }^{33}$

It was in North Africa where these men had to come to terms with the shock of being taken prisoner and with their POW status, a task made all the more difficult by the negative attitude towards Italians. This was exacerbated by chaotic battle experiences, a perceived lack of leadership from their own command, and the ensuing disillusion of being handed over to an "inferior" enemy, lack of food and water and the exploitative behaviour of both Italian and Senussi guards.

\section{Phase Two: From Bad to Worse}

For the most part, POW testimony of their experience in North Africa is characterised by negative statements and expressions of hatred towards the Italians and Senussi guards. However, when POWs were transported by cargo ships to Italy, the testimonies begin to reflect a more varied outlook among the POWs. While in the main the experiences on the cargo ships were horrific, there were isolated examples of POWs who viewed their transport to Italy in a more positive light. However, this is ironic as in some cases, the testimony contradicts the actual experience. It is almost as if some POWs started to display an attitude of resigned acceptance of their fate as they moved further away from the African continent.

Although the journey from Africa to Italy only lasted between five and ten days, many POWs blamed the Italians for intentionally creating poor conditions on the ships. The POWs were also of the opinion that their captors deliberately inflicted torment on their captives. Cargo spaces were packed to capacity with men, and movement was severely limited. The lack 
of toilet facilities below deck was a severe problem to which the Italians responded by providing buckets, but as most POWs were by now afflicted by dysentery, this provision was utterly inadequate and men found themselves lying or sitting in bodily waste.

In some instances, men were allowed to go on deck to use the toilet facilities there, but most dysentery cases were too weak to climb the ropes or rope ladders that were lowered into the hold. In any event, toilets on deck were not necessarily much better, as in some examples it meant nothing more than a bucket system requiring men to balance on a pole suspended over the container. ${ }^{34}$ At night, hatches over the holds were closed, which resulted in at least one death as a result of suffocation on the Rosalina Pilo, a ship that transported POWs from Benghazi to Tripoli in August 1942. ${ }^{35}$

For David Brokensha's brother Paul, the journey to Italy was the low point of his entire POW experience, and in his memoirs, David recalled how the usually optimistic Paul exclaimed, "God? There is no God."36 In contrast, Michael de Lisle remembered how they became "drunk on sugar" when they discovered food on their ship. The provisions were to be delivered to Italian soldiers at Tripoli from where the POWs would then continue to Italy. Even when the Italians realised that the prisoners had helped themselves to the foodstuffs, the POWs seemingly did not display any fear at the Italians who started "[s]hooting left and right and threatening us with all sorts of terrible tortures". ${ }^{37}$ On another occasion, De Lisle had time to enter into amicable conversation with German anti-aircraft soldiers who were also aboard the same ship. ${ }^{38}$

Another example of blame for suffering aimed at the Italians was the case of the events surrounding the San Sebastian. This ship, carrying mostly prisoners who had been captured during the Battle of Sidi Rezegh, was torpedoed by HMS Porpoise in December 1941, resulting in the deaths of between 350 and 450 men. ${ }^{39}$ The pandemonium that resulted following the attack on the ship and the Italians' panicky response to it once again served to further dent the POWs' opinion of their Italian captors. At least two South Africa POWs on board the San Sebastian insisted that the ship's captain and most of the officers used the lifeboats to save themselves while many of the POWs were being sucked underwater by the ship's propellers as they tried to swim to shore. ${ }^{40}$ Both Mason and Gilbert corroborate the 
abandonment of the ship by the Italian captain and crew and both record that a German naval engineer then took command. ${ }^{41}$ Yet, the available historical record is not certain in its details.

From POW testimony, it is clear that none of the South Africans took into consideration the Italian lack of preparedness for the vast number of prisoners. Their hardship while on board the ships were simply seen as another form of punishment. Events beyond the Italians' control, such as the torpedoing of the San Sebastian, were also not taken into consideration by the POWs, who simply viewed their suffering as the result of Italian vindictiveness towards their captives as well as the Italian lack of organisational ability.

\section{Phase Three: Work and Liberty}

Disembarking on Italian shores was for many POWs a shock. Seeing the bad state of both the civilians and the country overwhelmed many, mainly because it illustrated to them how their attitude towards the Italians were shaped by their bad experiences in North Africa. It was especially the Italian civilians whose actions towards the POWs made it clear to the captives that it was necessary to differentiate between groups when forming opinions on Italians. Civilians and the armed forces were the two main groups, but among them there were soldiers and camp guards, officers and rank and file, as well as Fascists and Partisans. Contact between POWs and each of these groups resulted in different viewpoints and perceptions regarding Italians.

When the POWs arrived in Italy, the way in which their attitudes were formed towards their captors were once again changed by external circumstances. The majority of South Africans arrived at Brindisi and were sent to Camp 85 in Tuturano or Camp 75 near Bari. At this stage of their journey, many were still suffering from dysentery and virtually all were fighting a losing battle against a severe lice epidemic. Many associate their arrival in Italian camps with a chance to be deloused, hot showers, haircuts and receiving additional clothing. From here, many POWs were given the opportunity to volunteer for work, mostly on farms or in factories. ${ }^{42}$ 
Those who chose to remain in the larger permanent prison camps were dependent on their captors for food and clothing and they were less able than POWs in work camps to improve their living conditions with regard to accommodation. As a result, many POWs retained their initial rancour towards the Italian military. Luyt was of the opinion that the "conditions [in the camps] were not good because the Italians couldn't organise, $[\ldots]$ there was always some stupid argument [about the lack of food] pure rotten organisation by the Italians". ${ }^{43}$ On the other hand, it was upon their arrival in Italy that South African POWs received their first Red Cross parcels, and although they had to share the contents, it lifted their spirits enormously. Dick Dickinson of the Transvaal Scottish Regiment states, "of course our Red Cross parcels made a hell of a difference, we couldn't have lived without those parcels", ${ }^{44}$ while Herbert Rhodes (Aussie) Hammond of the $1^{\text {st }}$ Brigade Signal Corps describes the arrival of the first Red Cross parcels at Tuturano camp as an event that "sent prisoners wild with joy." 45 Hindshaw and his fellow POWs were told that each parcel had to be shared between ten men, ${ }^{46}$ and, according to Mugglestone, the first Red Cross parcels that arrived at Camp 82 had to be shared between 18 men. Nevertheless, the prisoners were so happy to receive their consignments that their applause caused those guards who were unaware of the arrival of parcels to assume that the war had ended, for "they slung their rifles away and started dancing and cheering with the prisoners". ${ }^{47}$

The arrival of Red Cross parcels changed the balance of power between captives and captors, as it allowed the prisoners to use the contents to barter with the guards. Hindshaw remembers that some Red Cross items were more valuable than others, especially "coffee, chocolates and cigarettes, oh, you could bargain for anything on those things, but it was all on the side". ${ }^{48}$ Stanley Smollan of the Transvaal Scottish Regiment also remembers, "when those parcels first arrive the tables were turned because we had the food and the money". ${ }^{49}$

While the South African POWs in Italy viewed their Red Cross parcels as a great improvement to their recent circumstances, authorities in Pretoria did not feel the same. It was felt that Union POWs in Italy would endure

... great hardship owing to lack of adequate food and clothing if anything 
should happen to cause a serious dislocation of Red Cross parcel supplies [and] that it be established beyond doubt that Italian Government are in fact carrying out their obligations under the Prisoners of War Convention. ${ }^{50}$

The vulnerability of the Union's POWs was underlined by comparison of their circumstances with those of Italian POWs in South Africa who were, according to Squadron Leader Keeling of the British Red Cross Society, "receiving, quantitatively, three times as much food as our men in Italy are receiving". ${ }^{51}$ Similarly, Smollan considered Italian POWs in the Union as "very lucky indeed because they had a wonderful life [in South Africa] and they were looked after, for us it was just the opposite". ${ }^{52}$

Not all POWs in Italy, however, relied on Italian authorities for their welfare, and when the opportunity to volunteer for work parties came up, it was seen as a chance to improve their food supply and accommodation. Farm work allowed POWs to establish relationships with Italian civilians, as often the farmers were put in charge of, or worked alongside the POWs. The greater freedom on the farms made it possible for POWs to take a more active role in their own fate, they were able to use their initiative to arrange their living conditions and they were able to access more food. As Hindshaw states, "we went out working, which was actually a Godsend, [be]cause in the Prisoner-of-War camps, the food was too ghastly, the amount .... ${ }^{, 3}$ Brokensha fondly recalls how they volunteered for farm work during the Italian summer,

... and that was lovely, just to go out and it wasn't very hard [work] and then [during lunchtime] we'd strip and put all our clothes in a big pile and the guards would lie on [our clothes] and [we would] swim down the Tiber and sometimes girls would come over, [...] but the guards knew that we couldn't escape you know. ${ }^{54}$

When writing his memoirs, Brokensha even compared the scene next to the Tiber to a romantic Breughel painting. ${ }^{55}$

Although most POWs in work parties seemed testify to improved relationships between them and their captors, feelings of animosity from the POWs towards their guards remained and became evident in their behaviour. In Schwikkard's work party, for instance, a POW exchanged his old uniform for a sentry's new uniform, which the sentry had washed and 
hung to dry on the barbed wire of the camp. After a few weeks, the culprit was caught, but the POWs convinced the Italian officer that the sentry should join the POW in the cooler as the barbed wire he used as a drying rack actually belonged to the POWs! ${ }^{56}$ In another example, Hindshaw's group used to invite the guards to join them in playing games. One of the games was bok-bok (high cockalorum), and for the POWs it was a matter of pride to make sure that the Italians "were bucked down first!" 57

Throughout the summer months of 1943, rumours about an armistice reached POWs in camps across Italy, and during this time of uncertainty, the relationship between POWs and Italians underwent yet another change. Matthys Beukes of the President Steyn Regiment believed that the Italians feared retaliation from the POWs as a result of the bad treatment they had meted out in the past. ${ }^{58}$ Hindshaw remembered that at first, guards became very friendly when they heard of Mussolini's toppling, and then, when the Armistice was finally agreed, "every sentry bar one changed into civvies and destroyed his rifle". ${ }^{59}$ While still in North Africa, most POWs were of the opinion that the Italians were unworthy adversaries, but the way most Italian guards reacted when they heard about the armistice, confirmed to POWs that the Italians were never committed to war in the first place.

Initially, POWs regarded the armistice as a sign that their captivity was coming to an end. For many, this was indeed the case, as thousands of POWs walked out of prison camps as Italian guards abandoned their posts. However, for many POWs, the decision to leave camp was a difficult one, as rumours from various sources, including from Italian guards and civilians, seemed to indicate that the Allies were about to initiate an elaborate rescue plan. Michael de Lisle recalls that there were "tremendous rumours of landing[s] up the coasts of Italy on both sides". ${ }^{0}$ He also remembers, however, that another message, supposedly sent from a MI9 source, urged POWs to remain in their camps and warned of "disciplinary action to prevent individual prisoners of war attempting to rejoin their own units". ${ }^{61}$ The confusion was universal among all Allied POWs and of those who escaped many were confronted by Italians who tried to convince them not to continue their journeys to Allied territory, but to wait for the imminent arrival of the Allied forces. ${ }^{62}$ 
It would be impossible to determine the number of South African POWs who escaped successfully after the armistice, however, of the 79000 Allied POWs, almost 50000 left their Italian camps in August 1943. German forces, however, recaptured most of them and a year later, only 4000 arrived in neutral Switzerland and 6500 managed to reach Allied lines. $^{63}$ A total of 896 South African POWs, all escapees from Italy, managed to enter Switzerland. ${ }^{64}$ Many escaped South Africans, however, decided to remain among the Italians, fighting alongside the Partisans, while others lived among peasants or in the mountains, waiting for either the Allies or the end of the war. ${ }^{65}$

Those who managed to evade recapture by German forces became reliant on Italian peasants for food, shelter and information. It was during this stage of their experience, that POWs formed a positive attitude towards the Italian peasants, and in some cases, some POWs even joined the partisan movement and fought alongside their new-found allies. ${ }^{66}$ Fred Geldenhuis was one of those who managed to successfully escape after the armistice. He returned to Italy and fought alongside the Partisans, was recaptured by the Germans and sent to Stalag VIIA Moosburg, one of the largest German prison camps. While still in Italy, such a strong bond developed between Geldenhuis and his Italian allies, that the dedication his memoirs, $A$ Soldier's scrapbook, reads

... let me not forget to mention the Italian people who so ably assisted and fed us while in the mountains, many times at their peril and with dire consequences. Without their help and kindness many of us would not have survived. To the young Italians who, with threats of death from fascists and Germans, were willing to join the partisan forces, many of who fought side by side with me. Many were executed after being captured. I will always remember them. ${ }^{67}$

Smollan experienced a similar change of heart when he escaped and became dependent on Italian peasants for his welfare. In particular, it was his experiences with the Venetonni and De Lellis families, as well their cooperation with the Italian partisans, that convinced Smollan that most Italian peasants were essentially good natured. ${ }^{68}$ After his return to Allied forces at Anzio in February 1944, Smollan returned to South Africa and decided to repay his debt to his Italian collaborators by attempting to secure the release of the son of the De Lellis family. Tammasso De Lellis, a 
member of Italy's Fascist forces, had been a POW in the Zonderwater prison camp near Pretoria. Upon his return to South Africa, Smollan started sending food parcels to De Lellis, and in September 1946, Smollan wrote to the adjutant general in Pretoria in an attempt to secure "priority repatriation in consideration of services rendered to myself and other South Africans in assisting [with] escape from Italy" ${ }^{69}$ Although it seems that the authorities in South Africa were willing to facilitate the repatriation, De Lellis was required to sign a document stating his compliance to cooperate with the Allies. ${ }^{70}$ In a personal conversation between De Lellis and Smollan, the Italian POW admitted that he could not openly declare his collaboration "from fear of his comrades' reaction, [and also] from personal humiliation he would have to suffer in deserting [Fascist] principles he as stood by for so long". ${ }^{71}$ Smollan continued to support De Lellis and even tried to convince the authorities that De Lellis be made available for work outside of the camp. However, the matter came to a disappointing end when the Zonderwater camp commander finally informed Smollan October 1946 that De Lellis was

... afforded every opportunity to acquire Co-operator benefits [but] he resolutely declined to abandon his adherence to Fascist principles and designation, except upon the condition that he be transferred from this camp [and] it would appear that there is nothing further to be done in the matter, and that to continue to pursue it would serve no useful purpose. ${ }^{72}$

The fact of the matter was that De Lellis agreed to pledge his cooperation if he was able to do so away from his fellow POWs, but as there were no other POW camps in South Africa, it was not possible to transfer him. Smollan's attempts at reparation were therefore unsuccessful. ${ }^{73}$

\section{Conclusion}

Perhaps the most accurate description of South African POW attitude towards Italians is Michael de Lisle's summary in which he differentiates between the different groups in Italy. According to De Lisle, the ordinary Italian soldiers in North Africa were "despised as being lapdogs of the Germans". When the South Africans reached Italy, they formed friendships with the camp guards and realised the guards were "poor downtrodden conscripts, their heart wasn't in [the war]". De Lisle also made it clear that 
the Italian officers were taking advantage of their position and displayed "scorn for their private soldiers". Like many others who escaped following the armistice, De Lisle's attitude towards the civilian population, especially the peasants, changed dramatically. Most escapees felt they owned these people a huge debt of gratitude. As De Lisle said, they were "people with hearts of gold, and I just owe my life to them for the risks they took in feeding us when the penalties [were] enormously severe". ${ }^{74}$

Looking at the experiences and the reactions to treatment from their Italian captors, it becomes clear that South African POWs changed their views of their captors as their own circumstances changed during the war. Each man in the Union Forces entered the war from his own unique context, but all of them experienced similar conditions when captured and all of them reacted similarly when confronted with the treatment meted out by their Italian captors. This indicates that the attitudes, whether they were positive or negative, displayed by South African POWs towards the Italians, were not just the result of a specific predetermined attitude held by the South Africans before they became POWs. Their attitudes and reactions towards the Italians were equally the result of their response to the external events after capture, and not simply a result of the fact that their captors were Italian.

$1 \quad$ M Leigh. Captives courageous: South African prisoners of war World War II. Johannesburg: Ashanti, 1992.

2 P Schamberger. Interlude in Switzerland: The story of the South African refugee-soldiers in the Alps during the Second World War. Johannesburg: Maus, 2001.

3 See for instance B Moore \& B Hately-Broad (eds). Prisoners of war, prisoners of peace: Captivity, homecoming and memory in World War II. Oxford: Berg, 2005; B Moore \& K Fedorowich. The British Empire and its Italian prisoners of war, 1940-1947. London: Palgrave, 2003; B Moore. "Unwanted guests in troubled times: German prisoners of war in the Union of South Africa, 1942-43”. The Journal of Military History 70/1. 2006. 63-90; SP Mackenzie. The Colditz Myth: British and Commonwealth prisoners of war in Nazi Germany. Oxford: Oxford University Press, 2004; AJ Kochavi. Confronting captivity: Britain and the United States and their POWs in Nazi Germany. Chapel Hill, NC: UNC Press, 2005; A Gilbert. POW Allied prisoners in Europe 1939-1945. London: John Murray, 2007.

$4 \quad$ B Moore \& K Fedorowich (eds). Prisoners of war and their captors in World War II. Oxford: Berg, 1996. 
R Absalom. "Hiding history: The allies, the resistance and the others in occupied Italy 1943-1945”. The Historical Journal 38/1. 1995. 111-131.

WW Mason. Prisoners of war: Official history New Zealand in the Second World War 1939-45. Wellington: Oxford University Press, 1954.

JF Vance. Objects of concern: Canadian prisoners of war through the twentieth century. Vancouver: UBC Press, 1994.

AM Grundlingh. "The King's Afrikaners? Enlistment and ethnic identity in the Union of South Africa's Defence Force during the Second World War, 1939-45”. Journal of African History 40. 1999. 351-365.

Gilbert op. cit., p. 208.

H Klein (ed). Springbok record. Johannesburg: South African Legion of the British Empire Service League, 1946, 182, 186.

$\mathrm{M}$ de Lisle. Over the hills and far away: My twenties in the forties. Unpublished, n.d., 19.

J Holland. Together we stand: Turning the tide in the west - North Africa 1942-1943. London: Harper-Collins, 2006, 37.

I Rosmarin. Inside story. Cape Town: WJ Flesch, 2009, v. Interview with David Brokensha, 10 September 2010, Fish Hoek.

Rosmarin op. cit., p. 11.

Department of Defence Archives (hereafter DOD) Union War Histories (hereafter UWH), Narrative Report (hereafter Narep) ME 13. Notes on interview on 18 November 1946 with Capt. DG Fannin ex-int offr 4 SA INF BDE.

DOD UWH, Narep ME 13. Report of Interview - Gen. HB Klopper DSO Maj. LCF Turner, Chief Narrator (Land) 6 May 1946.

C Somerville. Our war: How the British Commonwealth fought the Second World War. London: Weidenfeld and Nicolson, 1998, 139.

Interview with Clive Luyt, 19 May 2010, Cape Town.

Interview with EB (Dick) Dickinson, 4 December 2010, Mossel Bay.

Ibid.

Although Klopper's military experience in the field was limited, his competence as Divisional Commander only seems to have become a point of contention following the fall of Tobruk and the loss of nearly 33000 Allied troops. For more on the consequences regarding the loss of Tobruk, including the effect it had on relations between Great Britain and South Africa, see A Stewart. "“The Klopper Affair': Anglo-South African relations and the surrender of the Tobruk Garrison”. Twentieth Century British History 17/4. 2006. 516-544.

Interview with Fred van Alphen, 25 May 2010, Cape Town.

Interview with Fred Geldenhuis, 9 July 2010, Pretoria. Toe ons nou oorgegee het, was ek in generaal Kloppers se 'dugout', sal ek sê, en daar het ek hierdie 'Molotof cocktails' jy weet, dis hierdie handgranaat, die het ek 'geprime' daar by hom en toe ek nou teruggaan, toe sê hy "Sê maar ons gaan nou oorgee".

BE Schwikkard. My life briefly told. Unpublished, 1999, 25. 
Interview with Wessel Oosthuizen, December 2010, Hartenbos. Die Duitsers ... ek wil nou nie die Italianers sleg maak nie hulle ... hulle is darem nie die Duitsers nie, nee.

Leigh op. cit., p. 24.

Interview with William Hindshaw, 19 March 2010, Johannesburg.

G Friedman. The Piano War: A true story of love and survival in World War II. Claremont: David Philip, 2003, 158. Another example of positive relations between black and white South Africans is that of Harry Klein, a medical officer and his trusted batman, Nelson Koza. See J Crwys-Williams. A country at war 1939-1945: The mood of a nation. Rivonia: Ashanti, 1992, 382-387.

DIH Mugglestone. Destination unknown. Unpublished manuscript. N.d., 22. Mason op. cit., p. 196.

MMH, File B472: Memoirs of LG Tupper.

J Mortlock. The endless years: Reminiscences of the 2nd World War. Unpublished, 1956, 31.

Leigh op. cit., pp. 36-37.

Mugglestone op. cit., p. 25.

D Brokensha. Brokie's way: An anthropologist's story. Love and work in three continents. Fish Hoek: Amani, 2007, 81-82.

Interview with Michael de Lisle, 4 June 2010, Cape Town.

Ibid.

Leigh op. cit., p. 39. The details regarding the number of those on board and those who died do not correspond between different sources. Leigh states 2200 men boarded, while Whittaker states the number as 2100 . Bernard Schwikkard, who experienced the event as a POW onboard the ship, estimated the number of prisoners at 2500 , while Crwys-Williams put the number at "over two thousand".

Schwikkard op. cit., p. 26; DOD UWH Narep ME 3. Mr Whittaker Sidi Rezegh and captivity afterwards (Greece and Italy) related to Mrs GR de Wit by Mr Whittaker.

Gilbert op. cit., p. 49; Mason op. cit., p. 111.

Leigh op. cit., p. 60.

Interview with Clive Luyt, 19 May 2010, Cape Town.

Interview with EB (Dick) Dickinson, 4 December 2010, Mossel Bay.

J Chambers. For you the war is over: The story of HR (Aussie) Hammond.

Cape Town: Haum, 1967, 38.

W Hindshaw. An account of my experience as a prisoner-of-war and escapee in the Italian Alps during the Second World War. Unpublished, n.d., 14-15.

Mugglestone op. cit., pp. 28, 31.

Interview with William Hindshaw, 19 March 2010, Johannesburg.

Interview with Stanley Smollan, 15 March 2010, Johannesburg.

DOD Adjutant-General (hereafter AG) (POW) Vol. I. Telegram from Secretary for External Affairs, Cape Town, to High Commissioner, London, 22 March 1943.

DOD AG (POW) 1537 Vol. I. Correspondence Secretary for External Affairs to the Adjutant-General, 18 February 1943. 
Interview with Stanley Smollan, 15 March 2010, Johannesburg. Interview with William Hindshaw, 19 March 2010, Johannesburg. Interview with David Brokensha, 10 September 2010, Fish Hoek. Brokensha op. cit., p. 89. Interview with Bernard Schwikkard, 17 March 2010, Johannesburg. Interview with William Hindshaw, 19 March 2010, Johannesburg. The rules of the game, in English referred to as Bucca Bucca, are described in PG Brewster. "Some African variants of Bucca Bucca". The Classical Journal 39/5. 1944. 293-296.

Interview with Matthys Beukes, 2 February 2011, Bloemfontein. Die Italianers het al meer bevrees geraak dat as hulle ons vrylaat sal ons hulle moer, hulle was mos eers die groot base gewees, het almal rond gedonner ... Hindshaw op. cit., p. 27.

Interview with Michael de Lisle, 4 June 2010, Cape Town.

Gilbert op. cit., p. 283.

Absalom op. cit., p. 114.

Gilbert op. cit., pp. 287-288.

Schamberger op. cit., p. 6.

Of those interviewed for this study, only Matthys Beukes reached Switzerland. Stanley Smollan escaped with three others and rejoined the Allies at Anzio in February 1944. Michael de Lisle escaped, was recaptured and escaped again to eventually meet up with the Allies near Lucca in November 1944. With the help of Italian partisans, Bill Hindshaw managed to make his way all the way to Allied-occupied France by January 1945 . Clive Luyt and two fellow POWs lived in the mountains, surviving on handouts from Italian peasants until the end of the war.

Schamberger op. cit., pp. 11-12.

FJW Geldenhuis. A soldier's scrap book: The memoirs of Frederik Jacobus Wagenaar Geldenhuis. Unpublished, n.d., 5.

D Saks. "Long journey to Anzio: A Springbok escapee story". Military History Journal 14/5. 2009. 193-194.

Stanley Smollan private collection. Correspondence between Stanley Smollan and Adjutant-General, Directorate Italian Prisoners of War, 9 September 1946.

Following a long and complicated process of negotiations between Great Britain, the USA and Italy, it was decided that Italian POWs held outside the Mediterranean would be given an opportunity to become 'co-operators', which would allow authorities to use them in a wide variety of work. For more on Italian POWs in Allied hands, see K Fedorowich \& B Moore. "Cobelligerency and prisoners of war: Britain and Italy, 1943-1945”. The International History Review 18/1. 1996. 28-47; K Fedorowich. "Propaganda and political warfare: The Foreign Office, Italian POWs and the Free Italy Movement”. In B Moore \& K Fedorowich (eds), Prisoners of war and their captors in World War II, Oxford: Berg, 1996, 119-148. Interview with Stanley Smollan, 15 March 2010, Johannesburg. 
72 Stanley Smollan private collection. Correspondence between Stanley Smollan and Capt. Charlton, Camp Commander at Zonderwater Camp, 9 September 1956 and 2 October 1946.

73 Interview with Stanley Smollan, 15 March 2010, Johannesburg.

74 Interview with Michael de Lisle, 4 June 2010, Cape Town. 